\title{
Effect of Biochar on Chemical Forms of Cd in Rice
}

\author{
Ying $\mathrm{CAO}^{1}$, Xueyan $\mathrm{ZHANG}^{1}$, Jun MENG ${ }^{2 *}$, Tianhong $\mathrm{ZHAO}^{1}$ and Henan ZHANG ${ }^{1}$ \\ ${ }^{1}$ College of Agronomy, Shenyang Agricultural University, Shenyang 110866, China \\ ${ }^{2}$ Biochar Engineering Technology Research Center of Liaoning Province, Shenyang 110866, China \\ caoying1111@163.com,121443373@qq.com,mengjun1217@163.com
}

\begin{abstract}
A pot experiment of 'Shennong 9816' treated by $0,2 \mathrm{mg} \mathrm{kg}^{-1}$ cadmium(Cd) and $0,1.4,14 \mathrm{~g} \mathrm{~kg}^{\text {- }}$ ${ }^{1}$ biochar were conducted to investigate the effect of biochar on the chemical forms of $\mathrm{Cd}$ in rice. The sequence chemical extraction method was used to study chemical forms of $\mathrm{Cd}$ in roots, stems and leaves of rice. Results indicated that the highest Cd concentration in vegetative tissues was F3 (extracted by $1 \mathrm{M} \mathrm{Nacl}$ ), followed by F4 and F5 (extracted by $2 \% \mathrm{HAC}$ and $0.6 \mathrm{M} \mathrm{HCl}$, respectively). Biochar reduced Cd in F1 and F2 (extracted by $80 \%$ ethanol and $\mathrm{d}-\mathrm{H}_{2} \mathrm{O}$, respectively). In conclusion, biochar could reduce the pollution risk of $\mathrm{Cd}$ in the food chain, however, the effect of biochar detoxification had not worked from the total $\mathrm{Cd}$ contents of rice organs at tillering stage.
\end{abstract}

KEYWORD: Cd; biochar; chemical forms; rice.

\section{INSTRUCTION}

Cadmium (Cd), as a widespread heavy metal, is released into the environment due to the industrial and agricultural activities. Meanwhile, $\mathrm{Cd}$ can be absorbed by plants and highly accumulated in tissues. For humans, due to its high soil-plant mobility, Cd can be transferred to the food chain, posing a serious problem on safe food production to threaten human health [1].

There is some evidence that $\mathrm{Cd}$ chemical forms may be associated with tolerance and detoxification in plants. This is also proven by the study of $\mathrm{Cd}$ chemical forms in Phytolacca americana L. [2], Kandelia obovata (S., L.) Yong [3] and Porphyra yezoensis[4].

As one of the most important crops globally, especially in Asia, rice provides staple food for over $60 \%$ population in China. The $\mathrm{Cd}$ of rice is a important source adding the $\mathrm{Cd}$ to human body.

Previous studies were mainly concentrated on the accumulation of heavy metals, effect of heavy metals on plant growth, and effect of root exudates on heavy metal toxicity $[5,6]$. However, to our knowledge, few articles had reported how the biochar affects the chemical forms of $\mathrm{Cd}$ in rice.

Biochar is a stable carbon-rich product obtained from pyrolysis of biomass with little oxygen. It is a newly developed environmental remediation material and has garnered research attention in recent years. Biochar has multi-functional properties that make it a promising and effective environmental adsorbent to remove organic and inorganic pollutions in soil and water.

The purpose of this study was to estimate both the concentrations of $\mathrm{Cd}$ chemical forms in rice at different growth stages under different biochar and $\mathrm{Cd}$ levels and to explore the potential mechanisms behind these dynamics.

\section{MATERIALS AND METHODS}

\subsection{Soil and plant preparation}

Pot experiments were conducted at Shenyang Agriculture University, Liaoning province, China in 2014. The original brown soil used in this study was selected from farmland. The soil were air-dried, passed through a 5-mm sieve, weighted, and allowed $15.0 \mathrm{~kg}$ to be placed in plastic pots. The soil $\mathrm{pH}$ was 5.9 ; its organic matter content, alkalihydrolyzable $\mathrm{N}$, available $\mathrm{P}$ and available $\mathrm{K}$ were $1.18 \%, 107.33 \mathrm{mg}$ $\mathrm{kg}^{-1}, 34.52 \mathrm{mg} \mathrm{kg}^{-1}$ and $98.41 \mathrm{mg} \mathrm{kg}^{-1}$, respectively. The concentrations of total $\mathrm{Cd}$ and extractable $\mathrm{Cd}$ in soil were $0.15 \mathrm{mg} \mathrm{kg}^{-1}$ and $0.09 \mathrm{mg} \mathrm{kg}^{-1}$, respectively. Besides, the concentrations of total cadmium in biochar was $0.6 \mathrm{mg} \cdot \mathrm{kg}^{-1}$.

Shengnong 9816, a kind of rice seed, was selected in this experiment. When seedlings grew onto 5-leaf stage, the uniform plants were selected and transplanted to pot on $23^{\text {th }}$, May, 4 points per pot, 2 seedlings per point. Fertilizer was applied per pot after transplanting as follows: Urea $0.428 \mathrm{~g} \mathrm{~kg}^{-1}$ soil, $\mathrm{CaHPO}_{4} \cdot 2 \mathrm{H}_{2} \mathrm{O} 0.523 \mathrm{~g} \mathrm{~kg}^{-1}$ soil, $\mathrm{K}_{2} \mathrm{SO}_{4} 0.247 \mathrm{~g} \mathrm{~kg}^{-1}$ soil, and the urea $1.5 \mathrm{~g}$ was added to per pot at 
tillering stage. The plant was taken care of according to cultivation system. Sampling period: tillering stage, filling stage and dough stage.

\subsection{Laboratory processing and sampling strategy}

Two Cd treatments, $\mathrm{Cd} 0\left(\mathrm{Cd}=0 \mathrm{mg} \mathrm{kg}^{-1} \mathrm{DW}\right.$ soil $)$ and $\mathrm{Cd} 2\left(\mathrm{Cd}=2 \mathrm{mg} \mathrm{kg}^{-1} \mathrm{DW}\right.$ soil $)$, were jointly applied with three biochar $(\mathrm{C})$ treatments, $\mathrm{C} 0(\mathrm{C}=0$ $\mathrm{g} \mathrm{kg}^{-1}$ DW soil), C21 (C=1.4 $\mathrm{g} \mathrm{kg}^{-1}$ DW soil, 21 gram per pot ) and $\mathrm{C} 210\left(\mathrm{C}=14 \mathrm{~g} \mathrm{~kg}^{-1} \mathrm{DW}\right.$ soil, 210 gram per pot). The $\mathrm{Cd} 0$ and $\mathrm{Cd} 2$ treatments were obtained by mixing the original soil with $\mathrm{Cd}$. $\mathrm{Cd}$ as cadmium chloride was added to each pot. There are six treatments containing the controls (no biochar and $\mathrm{Cd}$ added) with 12 replicates. At harvest, the whole plants were separated into roots, stems and leaves. The roots were soaked in $20 \mathrm{~m} \mathrm{~mol} \mathrm{~L}^{-1} \mathrm{Na}_{2}-$ EDTA for $15 \mathrm{~min}$ to remove metal ions adhering to the root surface, and roots, stems and leaves were washed with distilled water. All plant samples were dried in an oven for $30 \mathrm{~min}$ at $105{ }^{\circ} \mathrm{C}$, and then at $70{ }^{\circ} \mathrm{C}$ to a constant weight through $2 \mathrm{~mm}$ sieve for further experiment. $\mathrm{Cd}$ concentrations of roots, stems and leaves were determined by mixed-acid $\left(\mathrm{HNO}_{3}-\mathrm{HClO}_{4}\right)$.

\subsection{Extraction of chemical forms of $\mathrm{Cd}$}

Tessier's sequential extraction procedure was used. According to reference [7], roots, stems and leaves were chosen by dry materials. Six Cd chemical forms were extracted in the order of the extraction solutions by $80 \%$ ethanol in F1, distilled water (d$\mathrm{H}_{2} \mathrm{O}$ ) in $\mathrm{F} 2,1 \mathrm{M} \mathrm{NaCl}$ in $\mathrm{F} 3,2 \% \mathrm{HAC}$ in $\mathrm{F} 4,0.6 \mathrm{M}$ $\mathrm{HCl}$ in $\mathrm{F} 5$ and $\mathrm{Cd}$ in the residue was $\mathrm{F} 6$.

Each of the pooled supernatant solution and the residue were then evaporated on an electric-plate at $75{ }^{\circ} \mathrm{C}$ to constant weight, then digested at $200{ }^{\circ} \mathrm{C}$ with an acid oxidative mixture of $\mathrm{HNO}_{3}: \mathrm{HClO}_{4}(4: 1$, $\mathrm{v}: \mathrm{v})$. Root, stem, leaves and extractable concentrations of $\mathrm{Cd}$ were tested by atomic absorption spectrophotometry (AAS, Hitachi Z5000, Japan),

\subsection{Statistical analysis}

All experimental data were analysis by the SPSS statistical software package (version 17.0) and Excel2010. All data reported in this experiment were presented as means \pm standard deviation (SD). Duncan's tests was used to determine the significant differences between means $(\mathrm{p}<0.05)$.

\section{RESULTS AND DISCUSSION}

\subsection{Cd accumulation and transformation}

Fig. 1 showed that the total $\mathrm{Cd}$ concentrations in different organs decreased following the order of dough stage $>$ filling stage $>$ tillering stage. Besides, the $\mathrm{Cd}$ concentrations in rice at three growth stages were highest in the roots, followed by the stems and leaves.

In addition, adding biochar to soil had significant effects on $\mathrm{Cd}$ concentrations in the roots and leaves $(\mathrm{P}<0.05)$.In the whole rice growth period, the $\mathrm{Cd}$ concentrations of $\mathrm{Cd} 2$ treatments in roots, stems and leaves were higher than those of $\mathrm{Cd} 0$ treatments. In $\mathrm{Cd} 0$ treatments, $\mathrm{Cd}$ concentrations were increased significantly $(\mathrm{P}<0.05)$ with the increasing of biochar at every growth stage. This might because the biochar used in this experiment itself contained a certain amount of $\mathrm{Cd}$. When biochar applied to the soil, the Cd released slowly over time, and to be absorbed by the rice finally. In $\mathrm{Cd} 2$ treatments, at tillering stage, $\mathrm{Cd}$ concentrations in roots and leaves increased with the increasing of biochar content. This showed the effect of biochar detoxification had not worked from the total $\mathrm{Cd}$ contents of rice organs. The reason needed to be further analyzed. At the other two stages, the change tendency of $\mathrm{Cd}$ concentrations in roots, stems and leaves were similar, all decreasing with increasing the amount of biochar, and achieved significant level $(\mathrm{p}<0.05)$. The reasons were probably multifactional. Firstly, biochar could increase soil $\mathrm{pH}$, reduce the concentrations of exchangeable $\mathrm{Cd}$. Only when the effective $\mathrm{Cd}$ concentrations in soil reduced, could the $\mathrm{Cd}$ absorbed by plants be decreased. Secondly, the heavy metal could be fixed by biochar, which could reduce the heavy metals exposure in rhizosphere and migration to the plants. Namgay et al. (2010) [8] found biochar could significantly reduce the effectiveness of corn biological $\mathrm{Cd}$. In this experiment, the heavy metal $\mathrm{Cd}$ in soil was fixed by biochar and meanwhile the effectiveness of $\mathrm{Cd}$ was reduced in this way. Thirdly, biochar could increase plant biomass and then would be diluting the $\mathrm{Cd}$ concentrations. Reference [9] reported that high biomass enabled peanut plants to retain larger amount of $\mathrm{Cd}$ within their vegetative tissues while maintaining a lower $\mathrm{Cd}$ concentrations due to dilution effect. But overall, in the whole growth period of rice, the $\mathrm{Cd}$ concentrations in roots, stems and leaves showed the tendency of roots > stems > leaves.

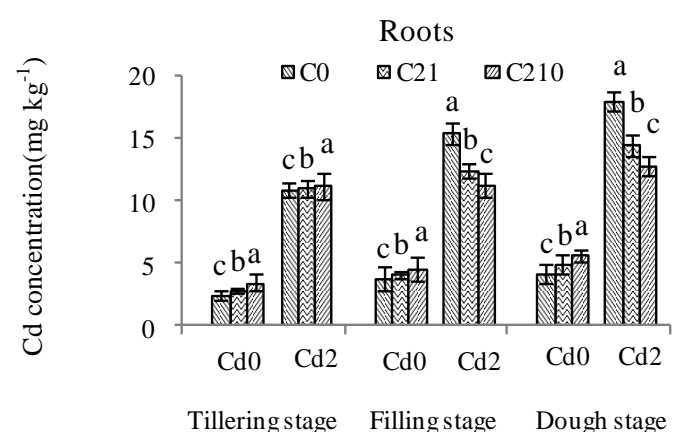

Treatment 


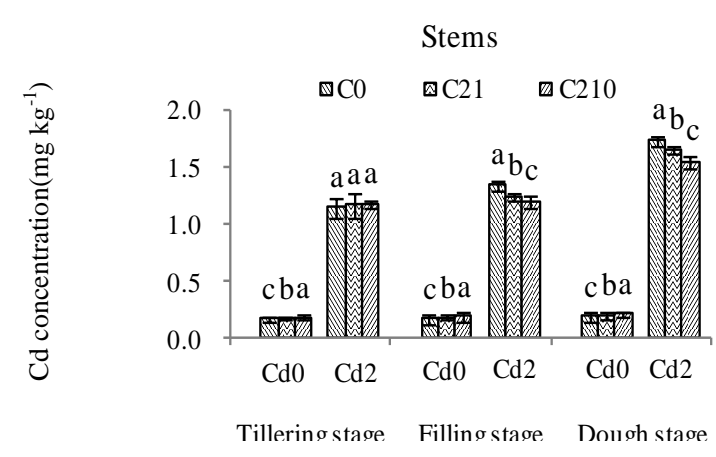

Treatment

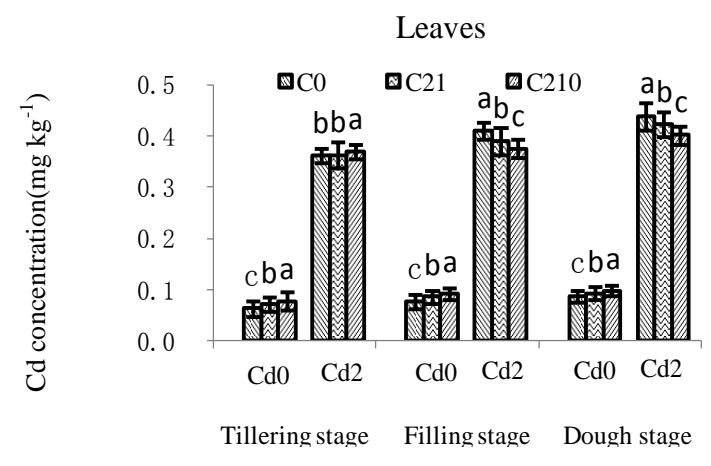

Treatment

\subsection{Chemical forms of $C d$}

Chemical forms of $\mathrm{Cd}$ in rice organs were explored under different biochar content (Table 1).

As showed in Table 1, Cd concentrations of different chemical forms were $\mathrm{Cd} 2>\mathrm{Cd} 0$. With the passage of growing period, the tendency of $\mathrm{Cd}$ concentrations of the same treatment was dough stage $>$ filling stage $>$ tillering stage. Besides, the concentrations of different chemical forms differed significantly among roots, stems and leaves. The study showed that both concentrations and percentage of $\mathrm{Cd}$ were clearly more in roots than in stems and leaves. We concluded that for the same treatment, the highest $\mathrm{Cd}$ concentration was F3 (extracted by $1 \mathrm{M} \mathrm{Nacl}$ ), followed by F4 and F5 (extracted by $2 \% \quad \mathrm{HAC}$ and $0.6 \mathrm{M} \mathrm{HCl}$, respectively), the rest forms were lower with the increasing biochar. In roots, the proportion of F3, F4 and F5 were respectively $36.54 \%-49.04 \%, 16.41-$ $31.00 \%$, 9.34\%-14.46\%. In stems, $29.74 \%-43.37 \%$, $17.70 \%-26.93 \%, 8.86 \%-13.27 \%$, respectively. In leaves, $35.49 \%-49.06 \%, 18.50 \%-26.79 \%, 8.23 \%$ $12.88 \%$, respectively. The six kinds of chemical forms were in the same plant, but the allocation proportion in roots, stems and leaves were different.

The chemical forms of heavy metals were closely related to their biological activities and detoxification in plant. The different chemical forms of $\mathrm{Cd}$ which could be extracted by different extracting agents related to the toxicity degree and migratory ability of $\mathrm{Cd}$. For instance, inorganic $\mathrm{Cd}$ $(\mathrm{F} 1$, extracted by $80 \%$ ethanol) and water-soluble $\mathrm{Cd}$
(F2, extracted by d-H20) exhibited remarkably stronger migratory capacity and were more deleterious to plant cells in comparison with undissolved $\mathrm{Cd}$ phosphate (F4) and Cd oxalic (F5) [10]. Previous studied related to $\mathrm{Cd}$ tolerance in Kandelia obovate (S., L.)Yong [3] also showed that a majority of $\mathrm{Cd}$ both in roots and leaves was associated with pectates and proteins (F3), followed by $\mathrm{Cd}$ phosphate complexes (F4). This conclusion was the same as ours. Of course, there were different results. For example, in Phytolacca americana L. F3 was the dominating form of $\mathrm{Cd}$ in leaves and stems, but the subdominant traction was F1 [2]. These differences might due to the varied $\mathrm{Cd}$ and biochar levels applied or the diverse plant species tested. F1 and F2 were mainly combined with nitrate ions, chlorides, organic acids and dihydric phosphates [11], which contributed most of Cd stress in plants. However, F3 was found to bind to proteins and pectic acids, while the pectic acids could fix the $\mathrm{Cd}$. As $\mathrm{Cd}$ had a strong affinity to proteins or sulfhydryl compounds (-SH) and other side chains, it could easily combine with proteins [12] and disturb the enzyme activity, so Nacl extractant might be responsible for the adaptation of plants to Cd stress. This was also the reason why F3 was the most in the body. Besides, F4, F5 and F6 showed the weakest migration activity and were less harmful to the plants.

There were significant differences in the $\mathrm{Cd} 2$ treatments with the different applying biochar content ( $\mathrm{p}<0.05)$, and the remediation effect of $\mathrm{C} 210$ was more obvious than C21. Compared with the treatment added no biochar but $\mathrm{Cd}$, in roots, each chemical extractant were reduced respectively by $42.57 \%, 48.41 \%, 30.63 \%, 20.71 \%, 10.67 \%, 14.97 \%$. In stems, $11.95 \%, 16.25 \%, 5.14 \%, 2.46 \%, 10.00 \%$, $3.33 \%$, respectively. In leaves, $16.18 \%, 18.46 \%$, $7.30 \%, 5.44 \%, 4.28 \%, 2.96 \%$, respectively. As could be seen in the six kinds of chemical speciation, F1 and F2 were fallen the most, which might because F1 and F2 had the strongest capacity of transformation, and it was the biochar that makd the $\mathrm{Cd}$ transformation from easily forms into difficult forms. To some extent, the biochar reduced the toxicity of $\mathrm{Cd}$ in rice.

From Table 1, we found that after adding biochar and $\mathrm{Cd}$, the $\mathrm{Cd}$ concentrations of different chemical forms among roots, stems and leaves existed significant differences. In the $\mathrm{Cd} 0$ treatments, the $\mathrm{Cd}$ concentrations of different chemical forms among roots, stems and leaves at three different growth stages were increased with the increasing biochar content. The percentage of F1, F2 increase and F4, F5 decreased (Table 1). In the $\mathrm{Cd} 2$ treatments, at tillering stage, the $\mathrm{Cd}$ concentrations and percentage of F1, F2 and F3 in roots, stems and leaves decreased with the increasing biochar content, while F4, F5 and F6 increased. At the other two stages, the $\mathrm{Cd}$ concentrations of different chemical forms in 
roots, stems and leaves decreased with the increasing biochar concentrations. Besides, the percentage of F1 and F2 decreased, F4 and F5 increased. Two group comparison results showed that biochar significantly enhanced both the concentrations and proportion of $\mathrm{F} 1$ and $\mathrm{F} 2$ for the $\mathrm{Cd} 0$ treatments, while it decreased in the $\mathrm{Cd} 2$ treatments. So the adsorption and detoxification effects of biochar were more obvious in the treatment added $\mathrm{Cd}$.

TABLE I Concentrations of different chemical forms of $\mathrm{Cd}$ in rice.

\begin{tabular}{|c|c|c|c|c|c|c|c|c|}
\hline \multirow{2}{*}{ Stages } & \multirow{2}{*}{ Organs } & \multirow{2}{*}{ Treatment } & \multicolumn{6}{|c|}{ Cd content $\left(\mathrm{mg} \mathrm{kg}^{-1}\right)$} \\
\hline & & & F1 & F2 & F3 & $\mathrm{F} 4$ & F5 & F6 \\
\hline \multirow{18}{*}{ Tillering } & \multirow{6}{*}{ Roots } & $\mathrm{C} 0 \mathrm{Cd} 0$ & $0.130 \pm 0.002 \mathrm{c}$ & $0.198 \pm 0.006 c$ & $1.202 \pm 0.028 \mathrm{c}$ & $0.538 \pm 0.016 \mathrm{c}$ & $0.392 \pm 0.016 \mathrm{c}$ & $0.267 \pm 0.014 \mathrm{c}$ \\
\hline & & $\mathrm{C} 21 \mathrm{Cd} 0$ & $0.150 \pm 0.005 b$ & $0.257 \pm 0.012 b$ & $1.373 \pm 0.018 \mathrm{~b}$ & $0.608 \pm 0.013 b$ & $0.419 \pm 0.010 \mathrm{~b}$ & $0.282 \pm 0.017 \mathrm{~b}$ \\
\hline & & $\mathrm{C} 210 \mathrm{Cd} 0$ & $0.281 \pm 0.014 \mathrm{a}$ & $0.333 \pm 0.016 \mathrm{a}$ & $1.660 \pm 0.038 \mathrm{a}$ & $0.718 \pm 0.018 \mathrm{a}$ & $0.488 \pm 0.021 \mathrm{a}$ & $0.296 \pm 0.009 \mathrm{a}$ \\
\hline & & $\mathrm{C} 0 \mathrm{Cd} 2$ & $0.728 \pm 0.221 \mathrm{a}$ & $1.260 \pm 0.321 \mathrm{a}$ & $5.079 \pm 1.406 \mathrm{a}$ & $2.020 \pm 0.688 \mathrm{c}$ & $1.401 \pm 0.421 \mathrm{c}$ & $0.436 \pm 0.205 \mathrm{c}$ \\
\hline & & $\mathrm{C} 21 \mathrm{Cd} 2$ & $0.560 \pm 0.115 b$ & $1.191 \pm 0.201 \mathrm{~b}$ & $4.816 \pm 0.553 b$ & $2.445 \pm 0.178 \mathrm{~b}$ & $1.478 \pm 0.218 \mathrm{~b}$ & $0.518 \pm 0.010 \mathrm{~b}$ \\
\hline & & $\mathrm{C} 210 \mathrm{Cd} 2$ & $0.532 \pm 0.110 \mathrm{c}$ & $0.824 \pm 0.151 \mathrm{c}$ & $4.658 \pm 0.418 \mathrm{c}$ & $2.998 \pm 0.640 \mathrm{a}$ & $1.535 \pm 0.090 \mathrm{a}$ & $0.639 \pm 0.035 \mathrm{a}$ \\
\hline & \multirow{6}{*}{ Stems } & $\mathrm{C} 0 \mathrm{Cd} 0$ & $0.016 \pm 0.002 b$ & $0.013 \pm 0.001 \mathrm{~b}$ & $0.065 \pm 0.005 b$ & $0.031 \pm 0.002 b$ & $0.017 \pm 0.002 \mathrm{a}$ & $0.013 \pm 0.001 b$ \\
\hline & & $\mathrm{C} 21 \mathrm{Cd} 0$ & $0.017 \pm 0.001 \mathrm{ab}$ & $0.014 \pm 0.002 \mathrm{~b}$ & $0.068 \pm 0.003 \mathrm{a}$ & $0.033 \pm 0.002 \mathrm{ab}$ & $0.017 \pm 0.002 \mathrm{a}$ & $0.013 \pm 0.006 \mathrm{~b}$ \\
\hline & & $\mathrm{C} 210 \mathrm{Cd} 0$ & $0.010 \pm 0.004 \mathrm{a}$ & $0.016 \pm 0.006 \mathrm{a}$ & $0.070 \pm 0.012 \mathrm{a}$ & $0.033 \pm 0.009 \mathrm{a}$ & $0.018 \pm 0.004 \mathrm{a}$ & $0.015 \pm 0.001 \mathrm{a}$ \\
\hline & & $\mathrm{C} 0 \mathrm{Cd} 2$ & $0.139 \pm 0.036 \mathrm{a}$ & $0.140 \pm 0.035 \mathrm{a}$ & $0.376 \pm 0.084 \mathrm{a}$ & $0.244 \pm 0.061 \mathrm{c}$ & $0.143 \pm 0.043 \mathrm{c}$ & $0.094 \pm 0.016 \mathrm{c}$ \\
\hline & & $\mathrm{C} 21 \mathrm{Cd} 2$ & $0.122 \pm 0.016 \mathrm{~b}$ & $0.127 \pm 0.022 b$ & $0.364 \pm 0.076 \mathrm{~b}$ & $0.297 \pm 0.012 b$ & $0.144 \pm 0.051 \mathrm{~b}$ & $0.105 \pm 0.013 b$ \\
\hline & & $\mathrm{C} 210 \mathrm{Cd} 2$ & $0.110 \pm 0.024 \mathrm{c}$ & $0.105 \pm 0.013 \mathrm{c}$ & $0.346 \pm 0.109 \mathrm{c}$ & $0.313 \pm 0.041 \mathrm{a}$ & $0.154 \pm 0.014 \mathrm{a}$ & $0.135 \pm 0.009 \mathrm{a}$ \\
\hline & \multirow{6}{*}{ Leaves } & $\mathrm{C} 0 \mathrm{Cd} 0$ & $0.004 \pm 0.001 \mathrm{a}$ & $0.005 \pm 0.001 \mathrm{a}$ & $0.029 \pm 0.002 \mathrm{a}$ & $0.013 \pm 0.001 \mathrm{a}$ & $0.006 \pm 0.001 \mathrm{a}$ & $0.006 \pm 0.001 \mathrm{~b}$ \\
\hline & & $\mathrm{C} 21 \mathrm{Cd} 0$ & $0.005 \pm 0.001 \mathrm{a}$ & $0.005 \pm 0.001 \mathrm{a}$ & $0.031 \pm 0.003 \mathrm{a}$ & $0.014 \pm 0.001 \mathrm{a}$ & $0.007 \pm 0.001 \mathrm{a}$ & $0.008 \pm 0.002 \mathrm{a}$ \\
\hline & & $\mathrm{C} 210 \mathrm{Cd} 0$ & $0.006 \pm 0.002 \mathrm{a}$ & $0.007 \pm 0.001 \mathrm{a}$ & $0.033 \pm 0.002 \mathrm{a}$ & $0.015 \pm 0.002 \mathrm{a}$ & $0.007 \pm 0.001 \mathrm{a}$ & $0.009 \pm 0.001 \mathrm{a}$ \\
\hline & & $\mathrm{C} 0 \mathrm{Cd} 2$ & $0.038 \pm 0.022 \mathrm{a}$ & $0.038 \pm 0.026 \mathrm{a}$ & $0.139 \pm 0.063 \mathrm{a}$ & $0.075 \pm 0.033 \mathrm{c}$ & $0.045 \pm 0.021 b$ & $0.026 \pm 0.020 \mathrm{a}$ \\
\hline & & $\mathrm{C} 21 \mathrm{Cd} 2$ & $0.036 \pm 0.011 \mathrm{~b}$ & $0.034 \pm 0.015 \mathrm{~b}$ & $0.133 \pm 0.042 \mathrm{~b}$ & $0.086 \pm 0.041 \mathrm{~b}$ & $0.047 \pm 0.032 \mathrm{ab}$ & $0.027 \pm 0.012 \mathrm{a}$ \\
\hline & & $\mathrm{C} 210 \mathrm{Cd} 2$ & $0.030 \pm 0.026 \mathrm{c}$ & $0.033 \pm 0.021 \mathrm{~b}$ & $0.131 \pm 0.039 \mathrm{~b}$ & $0.099 \pm 0.022 \mathrm{a}$ & $0.048 \pm 0.016 \mathrm{a}$ & $0.029 \pm 0.024 \mathrm{a}$ \\
\hline \multirow{18}{*}{ Filling } & \multirow{6}{*}{ Roots } & $\mathrm{C} 0 \mathrm{Cd} 0$ & $0.173 \pm 0.003 c$ & $0.241 \pm 0.004 \mathrm{c}$ & $1.873 \pm 0.027 \mathrm{c}$ & $0.714 \pm 0.019 \mathrm{c}$ & $0.511 \pm 0.014 \mathrm{c}$ & $0.316 \pm 0.008 \mathrm{c}$ \\
\hline & & $\mathrm{C} 21 \mathrm{Cd} 0$ & $0.235 \pm 0.008 b$ & $0.274 \pm 0.011 \mathrm{~b}$ & $1.947 \pm 0.041 \mathrm{~b}$ & $0.768 \pm 0.011 \mathrm{~b}$ & $0.554 \pm 0.011 \mathrm{~b}$ & $0.353 \pm 0.002 \mathrm{~b}$ \\
\hline & & $\mathrm{C} 210 \mathrm{Cd} 0$ & $0.294 \pm 0.019 \mathrm{a}$ & $0.368 \pm 0.003 \mathrm{a}$ & $2.121 \pm 0.014 \mathrm{a}$ & $0.864 \pm 0.008 \mathrm{a}$ & $0.591 \pm 0.005 \mathrm{a}$ & $0.371 \pm 0.016 \mathrm{a}$ \\
\hline & & $\mathrm{C} 0 \mathrm{Cd} 2$ & $0.832 \pm 0.209 \mathrm{a}$ & $2.067 \pm 0.237 \mathrm{a}$ & $6.400 \pm 0.940 \mathrm{a}$ & $4.045 \pm 0.583 \mathrm{c}$ & $1.514 \pm 0.129 \mathrm{c}$ & $0.614 \pm 0.066 \mathrm{c}$ \\
\hline & & $\mathrm{C} 21 \mathrm{Cd} 2$ & $0.678 \pm 0.194 b$ & $1.593 \pm 0.113 \mathrm{~b}$ & $4.636 \pm 1.099 \mathrm{~b}$ & $3.588 \pm 0.656 \mathrm{~b}$ & $1.488 \pm 0.162 \mathrm{~b}$ & $0.497 \pm 0.336 \mathrm{~b}$ \\
\hline & & $\mathrm{C} 210 \mathrm{Cd} 2$ & $0.567 \pm 0.144 \mathrm{c}$ & $1.224 \pm 0.089 \mathrm{c}$ & $4.149 \pm 0.698 \mathrm{c}$ & $3.517 \pm 0.838 \mathrm{a}$ & $1.463 \pm 0.126 \mathrm{a}$ & $0.424 \pm 0.199 \mathrm{a}$ \\
\hline & \multirow{6}{*}{ Stems } & $\mathrm{C} 0 \mathrm{Cd} 0$ & $0.011 \pm 0.002 b$ & $0.016 \pm 0.001 \mathrm{~b}$ & $0.068 \pm 0.006 \mathrm{c}$ & $0.031 \pm 0.002 b$ & $0.015 \pm 0.004 \mathrm{a}$ & $0.016 \pm 0.001 \mathrm{a}$ \\
\hline & & $\mathrm{C} 21 \mathrm{Cd} 0$ & $0.015 \pm 0.001 \mathrm{a}$ & $0.017 \pm 0.001 \mathrm{ab}$ & $0.071 \pm 0.014 \mathrm{~b}$ & $0.033 \pm 0.003 \mathrm{a}$ & $0.016 \pm 0.002 \mathrm{a}$ & $0.017 \pm 0.002 \mathrm{a}$ \\
\hline & & $\mathrm{C} 210 \mathrm{Cd} 0$ & $0.017 \pm 0.001 \mathrm{a}$ & $0.019 \pm 0.002 \mathrm{a}$ & $0.073 \pm 0.009 \mathrm{a}$ & $0.034 \pm 0.007 \mathrm{a}$ & $0.015 \pm 0.002 \mathrm{a}$ & $0.018 \pm 0.001 \mathrm{a}$ \\
\hline & & $\mathrm{C} 0 \mathrm{Cd} 2$ & $0.125 \pm 0.043 \mathrm{a}$ & $0.164 \pm 0.032 \mathrm{a}$ & $0.476 \pm 0.014 \mathrm{a}$ & $0.290 \pm 0.065 \mathrm{a}$ & $0.146 \pm 0.053 \mathrm{a}$ & $0.128 \pm 0.018 \mathrm{a}$ \\
\hline & & $\mathrm{C} 21 \mathrm{Cd} 2$ & $0.125 \pm 0.021 b$ & $0.137 \pm 0.043 b$ & $0.433 \pm 0.076 \mathrm{~b}$ & $0.286 \pm 0.041 \mathrm{~b}$ & $0.136 \pm 0.026 \mathrm{a}$ & $0.121 \pm 0.008 \mathrm{~b}$ \\
\hline & & $\mathrm{C} 210 \mathrm{Cd} 2$ & $0.123 \pm 0.032 \mathrm{c}$ & $0.125 \pm 0.016 \mathrm{~b}$ & $0.423 \pm 0.095 \mathrm{c}$ & $0.282 \pm 0.074 \mathrm{c}$ & $0.121 \pm 0.043 b$ & $0.120 \pm 0.021 \mathrm{~b}$ \\
\hline & \multirow{6}{*}{ Leaves } & $\mathrm{C} 0 \mathrm{Cd} 0$ & $0.004 \pm 0.004 \mathrm{a}$ & $0.006 \pm 0.003 \mathrm{~b}$ & $0.037 \pm 0.012 \mathrm{~b}$ & $0.014 \pm 0.004 \mathrm{~b}$ & $0.007 \pm 0.002 \mathrm{a}$ & $0.007 \pm 0.001 \mathrm{~b}$ \\
\hline & & $\mathrm{C} 21 \mathrm{Cd} 0$ & $0.005 \pm 0.002 \mathrm{a}$ & $0.008 \pm 0.002 \mathrm{ab}$ & $0.041 \pm 0.009 \mathrm{a}$ & $0.016 \pm 0.001 \mathrm{a}$ & $0.007 \pm 0.001 \mathrm{a}$ & $0.009 \pm 0.003 \mathrm{ab}$ \\
\hline & & $\mathrm{C} 210 \mathrm{Cd} 0$ & $0.006 \pm 0.001 \mathrm{a}$ & $0.009 \pm 0.002 \mathrm{a}$ & $0.041 \pm 0.021 \mathrm{a}$ & $0.017 \pm 0.003 \mathrm{a}$ & $0.008 \pm 0.001 \mathrm{a}$ & $0.010 \pm 0.001 \mathrm{a}$ \\
\hline & & $\mathrm{C} 0 \mathrm{Cd} 2$ & $0.044 \pm 0.021 \mathrm{a}$ & $0.042 \pm 0.041 \mathrm{a}$ & $0.158 \pm 0.073 \mathrm{a}$ & $0.089 \pm 0.041 \mathrm{a}$ & $0.049 \pm 0.021 \mathrm{a}$ & $0.029 \pm 0.008 \mathrm{a}$ \\
\hline & & $\mathrm{C} 21 \mathrm{Cd} 2$ & $0.040 \pm 0.012 \mathrm{~b}$ & $0.037 \pm 0.011 \mathrm{~b}$ & $0.151 \pm 0.055 b$ & $0.085 \pm 0.011 \mathrm{~b}$ & $0.048 \pm 0.011 \mathrm{ab}$ & $0.029 \pm 0.021 \mathrm{a}$ \\
\hline & & $\mathrm{C} 210 \mathrm{Cd} 2$ & $0.036 \pm 0.039 \mathrm{c}$ & $0.034 \pm 0.019 \mathrm{c}$ & $0.150 \pm 0.014 \mathrm{~b}$ & $0.082 \pm 0.009 \mathrm{c}$ & $0.047 \pm 0.009 \mathrm{~b}$ & $0.027 \pm 0.014 \mathrm{a}$ \\
\hline \multirow{18}{*}{ Dough } & \multirow{6}{*}{ Roots } & $\mathrm{C} 0 \mathrm{Cd} 0$ & $0.213 \pm 0.001 \mathrm{c}$ & $0.258 \pm 0.004 \mathrm{c}$ & $2.027 \pm 0.082 \mathrm{c}$ & $0.745 \pm 0.109 \mathrm{c}$ & $0.619 \pm 0.022 \mathrm{c}$ & $0.418 \pm 0.054 \mathrm{c}$ \\
\hline & & $\mathrm{C} 21 \mathrm{Cd} 0$ & $0.275 \pm 0.018 b$ & $0.324 \pm 0.012 b$ & $2.386 \pm 0.054 \mathrm{~b}$ & $0.805 \pm 0.016 \mathrm{~b}$ & $0.651 \pm 0.012 b$ & $0.463 \pm 0.010 \mathrm{~b}$ \\
\hline & & $\mathrm{C} 210 \mathrm{Cd} 0$ & $0.313 \pm 0.009 b$ & $0.399 \pm 0.004 \mathrm{a}$ & $2.764 \pm 0.071 \mathrm{a}$ & $0.938 \pm 0.044 \mathrm{a}$ & $0.705 \pm 0.020 \mathrm{a}$ & $0.516 \pm 0.058 \mathrm{a}$ \\
\hline & & $\mathrm{C} 0 \mathrm{Cd} 2$ & $1.012 \pm 0.171 \mathrm{a}$ & $2.660 \pm 0.374 \mathrm{a}$ & $6.826 \pm 1.219 \mathrm{a}$ & $4.944 \pm 1.134 \mathrm{a}$ & $1.676 \pm 0.231 \mathrm{a}$ & $0.822 \pm 0.015 \mathrm{a}$ \\
\hline & & $\mathrm{C} 21 \mathrm{Cd} 2$ & $0.755 \pm 0.212 b$ & $1.818 \pm 0.158 \mathrm{~b}$ & $5.374 \pm 0.761 \mathrm{~b}$ & $4.245 \pm 1.867 \mathrm{~b}$ & $1.526 \pm 0.148 \mathrm{~b}$ & $0.761 \pm 0.010 \mathrm{~b}$ \\
\hline & & $\mathrm{C} 210 \mathrm{Cd} 2$ & $0.581 \pm 0.106 \mathrm{c}$ & $1.372 \pm 0.257 \mathrm{c}$ & $4.735 \pm 1.056 \mathrm{c}$ & $3.920 \pm 0.992 \mathrm{c}$ & $1.497 \pm 0.314 \mathrm{c}$ & $0.699 \pm 0.084 \mathrm{c}$ \\
\hline & \multirow{6}{*}{ Stems } & $\mathrm{C} 0 \mathrm{Cd} 0$ & $0.016 \pm 0.001 \mathrm{~b}$ & $0.016 \pm 0.003 \mathrm{~b}$ & $0.075 \pm 0.012 \mathrm{c}$ & $0.033 \pm 0.003 b$ & $0.019 \pm 0.002 \mathrm{a}$ & $0.019 \pm 0.001 \mathrm{a}$ \\
\hline & & $\mathrm{C} 21 \mathrm{Cd} 0$ & $0.017 \pm 0.002 b$ & $0.019 \pm 0.001 \mathrm{a}$ & $0.078 \pm 0.024 \mathrm{~b}$ & $0.034 \pm 0.002 \mathrm{ab}$ & $0.020 \pm 0.002 \mathrm{a}$ & $0.020 \pm 0.001 \mathrm{a}$ \\
\hline & & $\mathrm{C} 210 \mathrm{Cd} 0$ & $0.020 \pm 0.004 \mathrm{a}$ & $0.021 \pm 0.006 \mathrm{a}$ & $0.082 \pm 0.005 \mathrm{a}$ & $0.035 \pm 0.001 \mathrm{a}$ & $0.020 \pm 0.001 \mathrm{a}$ & $0.021 \pm 0.002 \mathrm{a}$ \\
\hline & & $\mathrm{C} 0 \mathrm{Cd} 2$ & $0.202 \pm 0.041 \mathrm{a}$ & $0.235 \pm 0.032 \mathrm{a}$ & $0.549 \pm 0.043 \mathrm{a}$ & $0.378 \pm 0.014 \mathrm{a}$ & $0.205 \pm 0.015 \mathrm{a}$ & $0.150 \pm 0.008 \mathrm{a}$ \\
\hline & & $\mathrm{C} 21 \mathrm{Cd} 2$ & $0.188 \pm 0.024 b$ & $0.208 \pm 0.021 \mathrm{~b}$ & $0.535 \pm 0.086 \mathrm{~b}$ & $0.370 \pm 0.052 b$ & $0.192 \pm 0.018 b$ & $0.146 \pm 0.011 \mathrm{~b}$ \\
\hline & & $\mathrm{C} 210 \mathrm{Cd} 2$ & $0.178 \pm 0.013 \mathrm{c}$ & $0.196 \pm 0.005 \mathrm{c}$ & $0.521 \pm 0.021 \mathrm{c}$ & $0.369 \pm 0.017 \mathrm{~b}$ & $0.185 \pm 0.005 \mathrm{c}$ & $0.145 \pm 0.029 \mathrm{~b}$ \\
\hline & \multirow{6}{*}{ Leaves } & $\mathrm{C} 0 \mathrm{Cd} 0$ & $0.004 \pm 0.001 \mathrm{~b}$ & $0.007 \pm 0.002 \mathrm{~b}$ & $0.040 \pm 0.021 \mathrm{~b}$ & $0.017 \pm 0.003 \mathrm{a}$ & $0.009 \pm 0.001 \mathrm{a}$ & $0.010 \pm 0.001 \mathrm{a}$ \\
\hline & & $\mathrm{C} 21 \mathrm{Cd} 0$ & $0.005 \pm 0.004 \mathrm{ab}$ & $0.008 \pm 0.001 \mathrm{ab}$ & $0.042 \pm 0.009 \mathrm{ab}$ & $0.018 \pm 0.002 \mathrm{a}$ & $0.009 \pm 0.001 \mathrm{a}$ & $0.010 \pm 0.002 \mathrm{a}$ \\
\hline & & $\mathrm{C} 210 \mathrm{Cd} 0$ & $0.007 \pm 0.001 \mathrm{a}$ & $0.009 \pm 0.005 \mathrm{a}$ & $0.043 \pm 0.014 \mathrm{a}$ & $0.018 \pm 0.005 \mathrm{a}$ & $0.010 \pm 0.002 \mathrm{a}$ & $0.011 \pm 0.001 \mathrm{a}$ \\
\hline & & $\mathrm{C} 0 \mathrm{Cd} 2$ & $0.045 \pm 0.008 \mathrm{a}$ & $0.046 \pm 0.012 \mathrm{a}$ & $0.171 \pm 0.079 \mathrm{a}$ & $0.094 \pm 0.035 \mathrm{a}$ & $0.049 \pm 0.023 \mathrm{a}$ & $0.034 \pm 0.016 \mathrm{a}$ \\
\hline & & $\mathrm{C} 21 \mathrm{Cd} 2$ & $0.042 \pm 0.032 \mathrm{~b}$ & $0.041 \pm 0.041 \mathrm{~b}$ & $0.165 \pm 0.021 b$ & $0.093 \pm 0.071 \mathrm{a}$ & $0.049 \pm 0.015 \mathrm{ab}$ & $0.033 \pm 0.019 \mathrm{a}$ \\
\hline & & $\mathrm{C} 210 \mathrm{Cd} 2$ & $0.037 \pm 0.019 \mathrm{c}$ & $0.037 \pm 0.023 \mathrm{c}$ & $0.159 \pm 0.047 \mathrm{c}$ & $0.089 \pm 0.019 \mathrm{~b}$ & $0.047 \pm 0.042 b$ & $0.033 \pm 0.006 \mathrm{a}$ \\
\hline
\end{tabular}




\section{CONCLUSION}

In summary, plants cultivars differed in accumulation and translocation of $\mathrm{Cd}$, as well as its chemical forms. In rice, $\mathrm{Cd}$ analysis in different plant organs demonstrated that large proportion of $\mathrm{Cd}$ was stored in roots. This could be considered as the first barrier to defend itself against Cd toxicity. This study also concluded that $\mathrm{Cd}$ was accumulated high concentrations in the rice at dough stage than the other stages. Chemical forms research indentified most of $\mathrm{Cd}$ was extracted by $1 \mathrm{M} \mathrm{Nacl}$, which was integrated with pectates and protein, for $\mathrm{Cd}$ being fixed by pectic acids. Compared with $\mathrm{Cd} 0$ treatments, biochar deficiency could decrease $\mathrm{Cd}$ uptake and accumulation in rice. With increasing biochar content, F1 and F2, which had greater toxicity and stronger migration ability than the other forms of Cd decrease. However the effect of biochar detoxification had not worked from the total $\mathrm{Cd}$ contents of rice organs at tillering stage.

\section{ACKNOWLEDGMENT}

This work was supported by the Natural Science Foundation of China (41201317), Special Fund for Agro-scientific Research in the Public Interest (201303095), Science and Technology Project of Liaoning (2014215019) and Science and Technology Project of Shenyang (F15-199-1-19)

\section{REFERENCES}

[1] Y. Su, et al, "Effect of iron deficiency on subcellular distribution and chemical forms $\mathrm{Cd}$ in peanut roots in relation to its translocation," Environmental and Experimental Botany, vol.97, pp. 40-48, 2014.

[2] X.-P. Fu, et al, "Subcellular distribution and chemical forms of Cd in Phytolacca americana L.," Journal of Hazardous materials, vol. 186, pp.103-107, 2011.

[3] B.-S.Weng, et al, "Kandelia obavata (S., L.) Yong tolerance mechanisms to Cd:Subcellular distribution, chemical forms and thiol pools," Marine Pollution Bulletin, vol. 64, pp. 2453-2460, 2012.

[4] Y.-F. Zhao, et al, "Subcellular distribution and chemical forms of $\mathrm{Cd}$ in the edible seaweed, Porphyra yezoensis," Food Chemistry, vol. 168, pp. 48-54, 2015.

[5] X.-Y. Xie, et al, "The short-term effect of $\mathrm{Cd}$ on low molecular weight organic acid and amino acid exudation from mangrove (Kandelia obovata (S., L.) Yong) roots," Environmental Science and Pollution Research, vol. 19, pp.1-12, 2012.

[6] H.-L.Lu, C.-L.Yan, J.C.Liu, "Low-molecular-weight organic acids exuded by Mangrove (Kandelia candel (L.) Druce) roots and their effect on $\mathrm{Cd}$ species change in the rhizosphere," Environmental and Experimental Botany, vol, 61, no. 159-166, 2007.

[7] Y. Sun, "Effect of Si on rice biomass and chemical species of Cd under Cd stress," Southwest China Journal of Agricultural Sciences, vol.03, pp.1240 -1244, 2013.

[8] T. Namgay, B. Singh, B.-P. Singh, "Influence of biochar application to soil on the availability of $\mathrm{As}, \mathrm{Cd}, \mathrm{Cu}, \mathrm{Pb}$ and $\mathrm{Zn}$ to maize (Zea mays L.)," Australian Journal of Soil Research, vol. 48, no.7. pp. 638-647, 2010.

[9] G.-R.Shi, G.-Q Su, Z.-W. Lu, C.-F. Liu, X.-M. Wang, "Relationship betweem biomadd, seed components and Cd concentration in various peanut (Arachis hypogaea L.) cultivars grown on Cd-contaminated soils," Ecotoxicology and Environmental Safety, vol. 110, pp. 174-181, 2014.

[10] X. Wang, "Subcellular distribution and chemical forms of $\mathrm{Cd}$ in Bechmeria nivea (L.) Gaud," Environmental and Experimental Botany, vol. 62, pp. 389-395, 2008.

[11] F.-B. Wu, J. Dong, Q.-Q. Qian, G.-P. Zhang, "Subcellular distribution and chemical form of $\mathrm{Cd}$ and $\mathrm{Cd}-\mathrm{Zn}$ interaction in different barley genotypes," Chemosphere, vol.60, pp.1437-1446, 2005.

[12] L. Sanita di Toppi and R. Gabrielli, "Response to Cd in higher plants," Environmental and Experimental Botany, vol. 41, no. 2, pp. 105-130, 1999. 